\title{
ZвуSZKo MeLOSIK
}

\section{Izolacjonizm mniejszości, hybrydyzacja tożsamości i dylematy edukacji międzykulturowej}

Streszczenie: Artykuł poświęcony jest współczesnym dylematom edukacji międzykulturowej związanym z przemianami zarówno globalnej rzeczywistości, jak i tożsamości. Po omówieniu głównych idei edukacji międzykulturowej autor rekonstruuje zjawiska odnoszące się do asymilacji i izolacjonizmu mniejszości rasowych oraz etnicznych we współczesnych wielokulturowych społeczeństwach. Przywołuje różne konteksty enklawizacji, samowykluczania się i mniejszościowego etnocentryzmu oraz esencjalizmu, także w szkolnictwie, prowadzące do potwierdzania reprodukcji ekonomicznej i kulturowej. Pokazuje, w jaki sposób izolacjonizm mniejszości utrudnia realizację celów edukacji międzykulturowej. Następnie przedstawia przemiany współczesnej tożsamości, odnoszące się do procesów jej hybrydyzacji i wewnętrznej kulturowej heterogeniczności. Rekonstruuje wynikające z niej nurty krytyki edukacji międzykulturowej, dotyczące w szczególności idei dialogu między kulturami. Prezentuje różnorodne dylematy wynikające z „uwikłania” edukacji międzykulturowej w przemiany współczesnej wielokulturowej rzeczywistości. Przedstawia również wyzwania dla tej edukacji związane z pandemią Covid-19. W konkluzji autor przedstawia pozytywny potencjał dynamiki rozwojowej współczesnej edukacji międzykulturowej.

Słowa kluczowe: edukacja międzykulturowa, izolacjonizm mniejszości, etnocentryzm, asymilacja, tożsamość hybrydalna

Edukacja międzykulturowa kwestionuje europocentryczną wizję rzeczywistości i tożsamości, która jest punktem wyjścia polityki asymilacji mniejszości rasowych, etnicznych i narodowych, a jednym z jej ważnych instrumentów jest szkolnictwo. Rezygnuje się w tej edukacji z przekonania o uniwersalizmie założeń i wartości własnej kultury, co przynosi możliwość pozytywnego interkulturowego angażowania się. Jej istotą nie jest więc jedynie akceptacja kulturowej różnicy, ale podejmowanie zarówno przez grupy, jak i jednostki równoprawnych interakcji; intelektualnych, emocjonalnych i behawioralnych. (Palaiologou, 2014; Marginson i Sawir, 2011). Kategoria międzykulturowości 
stanowi odpowiedź na asymetryczne relacje między większością a mniejszością, także w odniesieniu do „politycznej i społeczno-ekonomicznej władzy”, jak również odpowiedź na „zaprzeczanie różnorodności, stygmatyzowanie odmienności i dyskryminację partykularnych grup” (Dietz, 2008, s. 2).

Eksponuje się w tym kontekście takie pojęcia, jak międzykulturowa komunikacja, świadomość, wrażliwość i dialog czy międzykulturowe kompetencje. Niekiedy pojawia się dosyć paradoksalne pojęcie „międzykulturowej asymilacji”, które odnosi się do swobodnego posługiwania się językiem innej kultury, posiadania pogłębionej wiedzy o niej (także w zakresie sztuki i historii), jak i umiejętności jej codziennego doświadczania. I to właśnie ma pozwolić na „bezproblemowe interakcje z osobami żyjącymi w odmiennym kulturowym środowisku" (Green, 2013, s. 12). Trzeba dodać, że edukacja międzykulturowa może mieć charakter instytucjonalny wówczas, gdy ma miejsce w szkołach (O’Halloran et al.), może jednak też urzeczywistniać się w układach nieformalnych i pozaformalnych (Lafraya, 2011).

Oczywiście edukacja międzykulturowa nie jest powszechnie akceptowana, pozostaje bowiem w sprzeczności z dominującym sposobem myślenia i dominującą tożsamością oraz stylem życia w krajach rasowo, etnicznie i narodowo zróżnicowanych. Poza tym jest także zwykle sprzeczna z interesami rządów, dla których najkorzystniejsza zarówno w znaczeniu politycznym, jak i ekonomicznym jest asymilacja mniejszości.

Głównym celem mojego artykułu nie jest jednak analiza przeszkód napotykanych przez edukację międzykulturową wskutek dominacji grupy większościowej, polityki dyskryminacyjnej czy funkcjonujących stereotypów związanych z przekonaniem o prymacie epistemologii, wartości i stylu życia Zachodu. W jego pierwszej części dokonam rekonstrukcji innego kontekstu ograniczeń dla tej edukacji. Odnosi się on do izolacjonistycznych tendencji przejawianych przez mniejszości rasowe, etniczne i narodowe (nie będę odnosił się jednak do przypadków separatystycznych żądań mniejszości dotyczących stworzenia własnego państwa, jak ma to miejsce na przykład w Katalonii). Z kolei w części drugiej przedstawię kontrowersje dotyczące tradycyjnego sposobu myślenia o edukacji wielokulturowej - w konfrontacji z występującymi w wielu społeczeństwach procesami de-esencjalizacji i hybrydyzacji tożsamości. Podkreślę również moje przekonanie, iż w warunkach postępującej globalizacji edukacja międzykulturowa posiada ogromny potencjał w zakresie konstruktywnego wpływu na rzeczywistość, chociaż konieczne jest wypracowywanie jej zróżnicowanych wariantów - w zależności od lokalnych potrzeb i warunków. 
Wyjdę od stwierdzenia, że izolacjonistyczna polityka mniejszości oparta jest przede wszystkim na celowej enklawizacji i gettoizacji. Związane są one zarówno ze świadomością (i dążeniem do pogłębienia „kulturowego oddzielenia"), jak i przestrzenią. W odniesieniu do tej drugiej kategorii Gunther Dietz pisze o zjawisku „terytorializacji”, które „polega na przekształceniu przestrzeni w terytorium", przy wyznaczeniu granicy między grupą, która je zajmuje, a innymi grupami (Dietz, 2009, s. 78). Tego typu separatyzm jest całkowicie sprzeczny z ideą międzykulturowości i edukacją międzykulturową.

Trzeba przy tym stwierdzić, że w warunkach masowej migracji „»enklawizacja« jest uważana za zjawisko normalne, ponieważ pomaga przyjeżdżającym migrantom, doświadczającym na początku szoku kulturowego i frustracji, dostosować się do nowych warunków zamieszkania i zatrudnienia" (Achkasov i Rozanova, 2013, s. 12). Oczywiście przyczynia się do niej znacząco również brak znajomości języka kraju-gospodarza. Zdaniem Herberta J. Gansa „Enklawy to miejsce stworzone przez rasowe, etniczne, religijne lub inne mniejszości, które (...) dokonują samo-segregacji z powodu odrębnego języka, kultury lub narodowości” (Podaję za: Achkasov i Rozanova, 2013, s. 26). Mamy tutaj do czynienia z dążeniem do zachowania swojej źródłowej tożsamości, która uważana jest za „jedynie uzasadnioną” (słuszne jest przecież stwierdzenie, iż fakt, że kultura stanowi „konstrukcję społeczną" nie czyni jej mniej realną dla ludzi w niej żyjących) (Jones, 2013, s. 2).

Oczywiście te zjawiska nie służą rozwijaniu międzykulturowych kontaktów, tym bardziej że towarzyszy im zjawisko etnocentryzmu grup mniejszościowych. Jego istotą jest, odwołując się do rozważań Stelli Tin-Toomey, przekonanie, że „wartości i normy naszej kultury są nadrzędne w stosunku do innych kultur, a nasze kulturowe sposoby życia są najbardziej uzasadnione" (por. Wrench et al., 2006, s. 24). Można też w tym miejscu przywołać pojęcie kolektywnego narcyzmu, określanego ,jako wiara w przesadzoną wspaniałość grupy, do której ktoś należy"; osoby poddające się kolektywnemu narcyzmowi deprecjonują inne grupy, a nawet wykazują wobec nich wrogość (Golec de Zavala et al., 2013, s. 49). W takiej sytuacji własna grupa mniejszościowa, podobnie, jak to ma miejsce w przypadku większościowych, znajduje się w centrum, stanowi główny (albo nawet jedyny) układ odniesienia, a inne mogą stanowić wobec niej jedynie „odchylenia” (Wrench et al., 2006, s. 24).

W kontekście tych zjawisk Cristian-Sorin Prun używa pojęcia „etnocentrycznych mniejszości” (Prun, 2020, s. 49), przywołuje się też jako przykład azjatycki etnocentryzm w Ameryce (Williams-Leo'n, 2003, s. 170); podaje się 
przypadki enklaw etnicznych, takich jak kubańska w Miami (Portes i Manning, 2008, ss. 58-61). Poniżej omówię ten problem w odniesieniu do Czarnych Amerykanów.

Francesco Mazzucotelli przywołuje w związku z izolacjonizmem mniejszości pojęcie „introwertycznej tożsamości” (Mazzucotelli, 2020, s. 29). W jednym z moich tekstów dla opisania konsekwencji opisanego wyżej zjawiska używałem pojęcia „tożsamość typu brzytwa”, dotyczącego „esencjalizowania określonej formy różnicy jako podstawy konstruowania tożsamości i odcinania wszystkiego tego i wszystkich tych, którzy »nie pasują «. Powstaje wówczas tradycyjna w swojej istocie antynomia »my-oni«, która stanowi źródło integracji grupowej i daje poczucie sensu" (Melosik, 2014, s. 181). Warto przytoczyć w tym miejscu stwierdzenie Gunthera Dietza, iż istotą procesu esencjalizacji jest „kategoryzowanie i stereotypizowanie”. Postrzega się jednostkę w taki sposób, jakby jej tożsamość była „esencjalnie zdefiniowana" przez sam fakt przynależności do jakiejś kulturowej lub etnicznej grupy (Dietz, 2007, s. 11). Taka przynależność może stanowić ważne źródło poczucia własnej wartości jednostki, dostarczać możliwości uzyskania poczucia statusu mimo marginalizacji w relacjach z dominującą większością, jak również chronić przed zewnętrznymi zagrożeniami (Leach et al., 2008, s. 761). Dodam, że niekiedy konstruowanie esencjalnej tożsamości nie jest związane z istnieniem grup rasowych, etnicznych czy narodowych, lecz stanowi reakcję na współczesne, prowadzące do dezintegracji tożsamości rozproszenie znaczeń, wartości i ideałów. Wówczas spójna oferta parafundamentalistyczna może stanowić źródło „rekonstrukcji czy reintegracji tożsamości w monolityczną całość, przy przyjęciu za oś określonego kryterium" (Melosik, 2014, s. 180) (np. dotyczy to subkultur młodzieżowych czy różnego typu sekt).

Nie ulega wątpliwości, że w praktyce mniejszościowe enklawy oraz związane z nimi symboliczne i przestrzenne granice nie tylko uniemożliwiają edukację międzykulturową, ale prowadzą także do samowykluczania się (Lehmann i Siebzehner, 2008, s. 238) (warto jednak w tym miejscu przywołać tezę, iż migranci integrują się łatwiej z rynkiem pracy, podejmując na przykład prace fizyczną niż w sferze kulturowej, gdzie czują silny związek ze „źródłową kulturą") (Yanasmayan, 2011, s. 25). Izolacjonizm rasowy, etniczny czy narodowy, stanowiąc formę protestu przeciwko asymilacji, potwierdza mechanizmy reprodukcji kulturowej i ekonomicznej, jak również istniejące stereotypy i uprzedzenia wobec mniejszości. 
Dodam, że niekiedy samowykluczanie się mniejszości stanowi formę walki o „polityczne rozpoznanie i inkluzję”. Oczywiście, także i w takiej formie prowadzi do "stworzenia i utrwalania społecznych i symbolicznych barier między daną grupą a resztą społeczeństwa" (i dodam od siebie - do blokady relacji międzykulturowych). A skutki są takie same: deprywacja ekonomiczna i marginalizacja społeczna (Lehmann i Siebzehner, 2008, s. 237).

Jestem oczywiście świadomy, że w każdym społeczeństwie problemy wielokulturowości i warunki urzeczywistniania edukacji międzykulturowej są odmienne i nie można dokonywać nieuzasadnionych uogólnień. Można tutaj na przykład przywołać liczne badania i opracowania polskich teoretyków i badaczy odnoszące się do specyfiki polskiej międzykulturowości (m.in. Nikitorowicz, 2017; Nikitorowicz, 2019; Lewowicki, Ogrodzka-Mazur i Szczurek-Boruta, 2011). Ale jestem też przekonany, że znakomitym przykładem opisanych wyżej zjawisk jest sytuacja czarnej społeczności w Stanach Zjednoczonych. Relacje między białą większością a czarną mniejszością były przez wieki zdominowane przez ideologię rasizmu i praktyki dyskryminacyjne. Wobec mniejszości tej stosowano również politykę asymilacjonizmu.

Również i obecnie, niezależnie od wszelkich zmian formalnoprawnych i społecznych, występuje w Stanach Zjednoczonych dążenie do homogenizacji tożsamości, do jej „amerykanizacji”, która oznacza narzucanie grupom mniejszościowym - za pomocą różnych, teraz już bardziej „miękkich” form - białej zachodniej protestanckiej tożsamości (Johnson i Pak, 2019, s. 4). Ma to miejsce zarówno poprzez różnorodne mechanizmy socjalizacyjne (w tym również szkolnictwo), rynek pracy i merytokratyczną ideę sukcesu społeczno-zawodowego, a także poprzez „wielką politykę" i środki masowego przekazu. W takiej sytuacji skuteczne urzeczywistnianie edukacji międzykulturowej jest bardzo trudne.

$\mathrm{Z}$ drugiej strony istnieje w Stanach Zjednoczonych zjawisko czarnego izolacjonizmu, który - jak już pisano wyżej - jest sprzeczny z ideałami i praktyką edukacji międzykulturowej. Jest on urzeczywistniany na poziomie makro i mikro; przyjmuje niekiedy formę jawnych praktyk społecznych, ale często jest „niewidzialny”, odbywa się na poziomie (pod)świadomości.

Warto dodać, że tendencje izolacjonistyczne czarnej społeczności w Stanach Zjednoczonych stały się nawet źródłem idei „czarnego nacjonalizmu”. Jego istotą było przekonanie o wspólnej historii i „wspólnym przeznaczeniu” Czarnych w tym kraju, ich wspólnych „interesach ekonomicznych i symbo- 
licznych" oraz konieczności zerwania relacji z Białymi (jego zwolennicy nie brali udziału w wyborach) (Carey, 2013). Zdarzało się też w przeszłości, że Czarni Amerykanie w walce z dominacją kultury białych podnosili to, co „czarne" do rangi tego, co absolutne i co tworzy jedyny akceptowany świat i jedyną możliwą do przyjęcia tożsamość. Esencjalizm w sferze czarnej tożsamości, co szczególnie wyrażało się w przestrzeni muzyki, opierał się na zmitologizowanym poczuciu wyższości nad kulturą białych, a nawet przekonaniu o uniwersalności kultury afrykańskiej (Swedenborg, 1992, ss. 56, 60, 63; Stephens, 1992, ss. 68-70).

Rzadko jednak czarny izolacjonizm przyjmuje formę zorganizowanego działania czy społeczno-politycznego radykalizmu (tak jak to miało miejsce w przypadku działającej w Ameryce kilka dekad temu organizacji „Czarne Pantery") (Street, 2010). Wyraża się on natomiast poprzez pewne zjawiska społeczne, których ciekawym przykładem jest występująca nadal segregacja rasowa w Stanach Zjednoczonych w zakresie „zamieszkiwania”. Oto Elizabeth Anderson twierdzi, iż powszechne decyzje Czarnych Amerykanów, którzy pragną żyć jedynie w sąsiedztwie innych Czarnych, wynikają w dużej mierze $\mathrm{z}$ „dobrowolnej (...) samo-segregacji”, związanej z czarnym etnocentryzmem. Trzeba jednak dodać, że istnieje również alternatywne wyjaśnienie tego zjawiska. I tak twierdzi się, że samo-segregacja jest skutkiem obawy przed „wrogością białych” (Anderson, 2010, s. 70). Wreszcie eksponuje się jako przyczynę tego zjawiska istniejącą stratyfikację społeczno-ekonomiczną (Anderson, 2010, ss. 70-71) - to bogatsi Biali unikają zamieszkania razem z Czarnymi. Niezależnie od zróżnicowania tych argumentacji, przestrzenna izolacja nie pozwala na kontakty międzykulturowe i na zmianę relacji społecznych.

Innym doskonałym przykładem izolacjonizmu i de facto wyrazem etnocentryzmu na poziomie mikro może być odrzucenie przez Czarną i Latynoską młodzież idei sukcesu szkolnego. Uważa ona, że sukces ten jest przesycony „białymi wartościami” i pozostaje w sprzeczności z Czarną/Latynoską tożsamością. W punkcie wyjścia można tutaj przypomnieć klasyczne badania Paula Willisa z lat 60. ubiegłego wieku, w których pokazywał on mechanizmy formowania się - opozycyjnej wobec szkoły - kontrkultury chłopców z rodzin robotniczych (Willis, 1981). Odrzucanie szkoły sprawiało przy tym nieuchronnie, iż w przyszłości „powielali” oni status swoich rodziców; występowała tutaj w swojej typowej formie reprodukcja kulturowa i ekonomiczna.

Podobna sytuacja występuje w przypadku części młodych Czarnych i Latynosów, którzy odrzucając kulturę szkoły, będą w przyszłości żyli na społeczno-ekonomicznym marginesie. Przywołam tutaj stosowane w amery- 
kańskiej socjologii edukacji pojęcie „działania jak Biali” [acting white], które odnosi się do „wyjaśniania (...) braków sukcesów szkolnych czarnej młodzieży” i tworzonej przez nich „kultury opozycyjnej” wobec białej kultury dominującej. Zastąpiło ono „uprzednie pojęcie intelektualnej niższości Czarnych, a to poprzez eksponowanie ich świadomej decyzji dotyczącej rezygnacji z sukcesów akademickich" (Durkee i Williams, 2015, s. 27). Trzeba dodać, że pojęcie „działania jak Biali” nie ogranicza się tylko do osiągnięć szkolnych, ale także sposobów mówienia i ubierania się oraz preferencji muzycznych; najogólniej - do stylu życia (Durkee i Williams, 2015, ss. 27-28). Wewnątrz czarnej społeczności występuje przy tym często dyskryminowanie tych Czarnych, którzy „działają jak Biali” (i dodam - chcą się dobrze uczyć, albo w ogóle się uczyć). Może to mieć bardzo negatywny wpływ na ich zdrowie psychiczne, a to $\mathrm{z}$ uwagi na oczywisty fakt, iż grupa rówieśnicza stanowi ważny układ odniesienia dla poczucia własnej wartości i tożsamości (Durkee i Williams, 2015, s. 28). Warto dodać, że w takiej sytuacji część czarnej młodzieży, aby ukryć swoje aspiracje szkolne, mówi „dwoma angielskimi” w zależności od sytuacji społecznej, w której się aktualnie znajduje. Potrafi płynnie przechodzić od "standardowego angielskiego" do slangowego „czarnego angielskiego” (Durkee i Williams, 2015, s. 28).

Dodam, że takie podejście znakomicie wpisuje się w tezę Gunthera Dietza, iż „język jest często instrumentalizowany (...) przez etnicznych aktorów jako »broń«” w obliczu groźby asymilacji (Dietz, 2009, s. 94). „Ucieczka” we własny język zdecydowanie utrudnia jednak urzeczywistnianie kontaktów międzykulturowych. Można tutaj przedstawić i inny ciekawy paradoks, związany z pojęciem „wigger” („white nigger” albo „white Negro”). Odnosi się on do tych młodych białych ludzi, którzy pragną odrzucić zachodnią kulturę i przyjąć „czarną” tożsamość i „czarny” styl życia, szczególnie w kontekście hip-hopu (Nayak, 2003, s. 107).

Również opublikowane w 2019 roku wyniki badań wśród czarnych i latynoskich studentów wykazały adekwatność pojęcia „działania jak Biali”, chociaż nie w odniesieniu do sfery akademickiej. Otóż część przedstawicieli mniejszości krytykowała takie zachowania i komponenty stylu życia swoich kolegów, które - ich zdaniem - nie były „autentycznie” czarne lub latynoskie. Największa krytyka odnosiła się do rezygnacji z używania etnicznego slangu. Podejmowano jednak również kwestię - jak to określano - „pretensjonalnego” lub „protekcjonalnego” zachowania tych czarnych i latynoskich studentów, którzy pochodzili z rodzin dobrze sytuowanych i żyli na relatywnie wysokim poziomie (Durkee et al., 2019, ss. 4-7). W tym przypadku występuje 
jednak pewien paradoks. Oto krytyczni wobec „działania jak Biali”, czarni i latynoscy studenci odrzucali co prawda „biały styl życia”, a w szczególności - poprawny „biały język”, ale studiując, akceptowali „białą”, merytokratyczną ideologię sukcesu edukacyjno-zawodowego.

Przypomnieć można także inny, bardziej radykalny przykład czarnego separatyzmu w Stanach Zjednoczonych, opisywany przeze mnie w jednej z wcześniejszych publikacji. Oto w latach 80. i 90. XX wieku - w okresie tak zwanej „politycznej poprawności” - grupy czarnych (i niekiedy i latynoskich) studentów tworzyły na uniwersytetach enklawy etniczne (Melosik, 2007, ss. 229-268). Niekiedy postulowano nawet tworzenie w ramach uczelni całkowicie oddzielnych „czarnych wydziałów”. W tym kontekście niezwykle ważne były organizacje studenckie dające swoim członkom „poczucie przynależności”. Niektóre z nich preferowały nawet politykę antyintelektualizmu, która uznawała dążenie do osiągania dobrych akademickich wyników za równoznaczne ze wspomnianym „działaniem na sposób białych” (D’Souza, 1991, ss. 232-234). Odrzucano kanon kultury, który obowiązywał na uniwersytetach. Twierdzono, że ma on charakter „biały”, rasistowski i seksistowski. Wielokrotnie przy tym organizacje mniejszości stosowały zasadę „wyłączności”, odrzucając wszelkie zasady i formy komunikacji międzykulturowej. Można tutaj podać przykład z University of Washington, gdzie studencki „Task Force on Ethnicity” odmówił nadania Włochom, Irlandczykom i Żydom „certyfikatu” grup etnicznych. John Taylor pisał w tym kontekście o „zazdrosnym chronieniu statusu represjonowanych grup" (Taylor, 1993, s. 22.). Z kolei Dinesh D'Souza podkreślał fakt samo-segregacji mniejszości na uniwersytetach i przekształcenie pluralizmu w separatyzm (D’Souza, 1991, s. 239, 244).

Oczywiście przedstawione wyżej odrzucanie kultury szkolnej i sukcesu szkolnego przez mniejszość nie odnosi się tylko do Stanów Zjednoczonych; na przykład w Wielkiej Brytanii robią to nagminnie młodzi ludzie z rodzin imigrantów z krajów Południowo-Wschodniej Azji (Pakistan i Bangladesz). Przy tym Gill Crozier i Jane Davies sugerują, że jest to forma oporu wobec „hegemonii kulturowej” kultury Zachodu, która dominuje w szkołach (Crozier i Davies, 2008, s. 285).

Przedstawiony powyżej problem izolacjonizmu mniejszości rasowych i etnicznych skłania do refleksji dotyczących teorii i praktyki edukacji międzykulturowej. Pierwsza z nich dotyczy dylematu, który uosabia pytanie: równość czy tożsamość? Trudno bowiem nie zauważyć, że wiele (i coraz więcej) osób z mniejszości rasowych czy etnicznych - że pozostanę przy przykładzie amerykańskim - kończy prestiżowe uczelnie i odnosi sukces społeczno-za- 
wodowy na warunkach zachodniego, liberalnego współzawodnictwa. Prowadzą one styl życia całkowicie oderwany od tradycyjnie "czarnego". Dla nich kategoria międzykulturowej wrażliwości czy kompetencji - w kontekście relacji społecznych w Stanach Zjednoczonych - jest pozbawiona większego sensu, bowiem rezygnują oni ze swojej źródłowej tożsamości.

Jak pisałem w jednej z moich książek: „(...) miliony ludzi z mniejszości, żyjących w (...) białych społeczeństwach Zachodu, postrzegają odmienny kulturowo komponent swojej tożsamości w większym stopniu jako styl niż jako autentyczny rdzeń. Dążąc do uzyskania sukcesu w białym społeczeństwie, bez wahania akceptują jego reguły gry" (Melosik, 2007, s. 209). Przy czym w przypadku Stanów Zjednoczonych: „Jednostka z grupy nieuprzywilejowanej stoi (...) przed dramatyczną alternatywą. Może ona $\mathrm{z}$ jednej strony próbować osiągnąć sukces na warunkach zdefiniowanych przez dominującą WASP [White Anglo-Saxon Protestants] i wykorzystać w tym celu - jako trampolinę - edukację. Jednak przejście przez pełny cykl kształcenia (...) w nieunikniony sposób zmusi ją do zerwania z tą wersją własnej biografii, która wyznaczona jest przez wartości jej grupy wyjściowej (rasowej bądź etnicznej). Może podjąć wysiłek, aby stać się »równa « w środowisku »epistemologicznie« dla niej obcym, poprzez stopniowe »wymazywanie« wartości własnej grupy (jako blokad sukcesu) i przyjmowanie wartości WASP (...). Z drugiej strony może ona kontynuować swoją dotychczasową biografię i dążyć do zachowania swojej tożsamości, np. etnicznej, rasowej; (...) jednak oznacza to jej społeczną marginalizację (...)” (Melosik, 2007, s. 217). „We współczesnym społeczeństwie amerykańskim występuje więc paradoks, wynikający ze »zderzenia« dwóch zjawisk: pluralizmu kulturowego (...) i zdominowania życia społecznego i trajektorii sukcesu przez wartości grupy dominującej. Paradoks ten można ukazać za pomocą antynomii: tożsamość czy równość?" (Melosik, 2007, s. 217). Oczywiście miliony czarnych Amerykanów decydują się na "równość" na prawach liberalnej Ameryki, co de facto oznacza poddanie się dobrowolnej asymilacji. W takiej sytuacji przedstawiciele mniejszości rasowych i etnicznych, powtórzę raz jeszcze, nie mają żadnych „międzykulturowych aspiracji”. Stają się oni bowiem częścią amerykańskiej, dobrze sytuowanej i zintegrowanej klasy średniej. I z pewnością w przypadku tej grupy nie potwierdza się teza, iż: „Etniczność jest bardziej pierwotna niż klasa. Krew jest ważniejsza niż pieniądze" (Diezt, 2009, s. 75). Rzeczywistość amerykańska bardzo zmieniła się od roku 1973, kiedy to Lerone Bennett pisał, w kontekście walki o zachowanie czarnej tożsamości: „dla czarnych w Ameryce jest tylko jedna gorsza rzecz od porażki w Ameryce - to znaczy odniesienie 
sukcesu w Ameryce" (podaję za: Forsythe, 1973, s. 6). A pięć lat wcześniej E. Franklin Frazer stwierdził: „...dla większości murzyńskich intelektualistów integracja Murzynów oznacza... pozbawienie ich życia znaczącej treści, a także pozbycie się przez ich całej murzyńskiej identyfikacji. Dla nich, integracja i ostatecznie asymilacja oznacza anihilację Murzyna - fizycznie, kulturowo i duchowo" (podaję za: Forsythe, 1973, s. 6).

Dla zrozumienia dylematów współczesnej edukacji międzykulturowej konieczne jest podjęcie jednego jeszcze problemu. Oto we współczesnym świecie tożsamości przestały być monolityczne. W przeszłości, w społeczeństwach, takich jak na przykład amerykańskie, kanadyjskie, brytyjskie czy australijskie, istniały grupy o jasno określonej tożsamości, opartej na rasie, etniczności czy narodowości. W takich warunkach konstruowanie programów edukacji międzykulturowej było oparte na jasnych przesłankach i odwoływało się do określonego języka, tradycji i stylów życia mniejszości. Pojęcia Biali, Czarni, Latynosi, mniejszość chińska czy włoska zawierały w sobie bardzo silne znaczenia. We współczesnym globalnym świecie, pełnym mobilności zarówno fizycznej, jak i digitalnej, jednoznaczne tożsamości tracą swoje znaczenie, a niekiedy przestają istnieć.

Dla określenia tego zjawiska przywołuje się w literaturze pojęcia odnoszące się do różnych, niekiedy pełnych wewnętrznych sprzeczności, wariantów tożsamości. Wymienię tutaj choćby tożsamość „płynną” czy „sfragmentaryzowaną”, rozproszoną lub „hybrydalną”. W kontekście edukacji międzykulturowej ta ostatnia odgrywa chyba największą rolę. Hybrydalność pozostaje w opozycji do esencjalistycznych i zamkniętych tożsamości. Niekiedy łączy się ona z „podwójną identyfikacją etniczną” (Leman et al., 2014, s. 18). „Tożsamość hybrydalna nie jest związana z monolitycznością lub zamkniętymi granicami [jaźni]” (Rygiel, 2018, s. 51). „Funkcją granic jest konstruowanie różnicy, a funkcją hybrydalności jest rozpuszczanie granic" (Marotta, 2008, s. 300). Można więc stwierdzić, że tożsamość hybrydalna cechuje się wewnętrzną heterogenicznością kulturową i wieloraką przynależnością grupową (Wagner, 2016, s. 242). Consuela Wagner pisze nawet o istnieniu „tożsamości sytuacyjnej”, której cechą jest umiejętność „przełączania kodów kulturowych", co umożliwia przejście z jednej do drugiej formy tożsamości (Wagner, 2016, s. 242).

I tutaj właśnie pojawia się kolejny dylemat edukacji międzykulturowej. Staje się ona, w kontekście istnienia tożsamości hybrydalnej, podatna na krytykę. Oto bowiem u podstaw tej edukacji znajduje się kategoria różnicy/różnorodności kulturowej i tożsamościowej. To ona postrzegana jest w sposób 
naturalny jako punkt wyjścia wszelkich projektów. Jeśli nie istnieje różnica/ różnorodność, to kategoria "między” jest pozbawiona sensu, ponieważ nie ma podmiotów czy partnerów, do których mogłaby się ona odnosić.

W tym aspekcie zarówno projekty wielokulturowości, jak i edukacji międzykulturowej są krytykowane za ich nieadekwatność w stosunku do współczesnych realiów społeczno-kulturowych i hybrydalnych form tożsamości. Twierdzi się, że w ramach tych projektów dokonuje się esencjalizacji różnicy, chociaż zupełnie z innych powodów, niż to ma miejsce w przypadku działań o charakterze etnocentrycznym. Zarzut dotyczy nieuprawomocnionego odwoływania się do różnic, które zdaniem krytyków obecnie już nie istnieją. Krytycy uważają, że w edukacji międzykulturowej różnice są sztucznie podtrzymywane, bowiem tylko wówczas można tworzyć interakcje typu „między” pewnymi wyodrębnionymi grupami. Jeśli tych grup nie będzie, gdyż różnice między nimi „rozpłyną się”, to wówczas nie ma możliwości zaistnienia interakcji.

Proponuje się w związku z tym odmienne „paradygmatycznie” myślenie, oparte na zakwestionowaniu zarówno „asymilacyjnej monokulturowości”, jak i „esencjalistycznej wielokulturowości”. Punktem wyjścia jest tu przekonanie, iż tożsamość etniczna, kulturowa, religijna, klasowa czy płciowa mają charakter "pluralistyczny, multi-sytuacyjny, kontekstualny, a w konsekwencji hybrydalny” (Dierz, 2018, s. 4). Tak więc „hybrydalność włącza częściowe tożsamości, wielorakie role i pluralistyczne jaźnie" (Smith, 2008, s. 5). Paolo Gomarasca twierdzi z przekonaniem, iż „kulturowa hybrydalność tworzy realną alternatywę dla esencjalistycznego modelu wielokulturowości, unikając przy tym naiwnej retoryki (...) międzykulturowego dialogu" (Gomarasca, 2013, s. 70).

W krytyce istniejących sposobów teoretyzowania i praktykowania edukacji międzykulturowej eksponuje się też fakt, że w ramach prowadzonej niekiedy polityki afirmatywnej traktuje się mniejszości jakby były „ginącymi gatunkami” i należało je za wszelką cenę „uchronić od wyginięcia”. To powoduje opartą na esencjalizmie, jak pisze Gunther Dietz, „etnicyzację różnorodności" (Dietz, 2007, s. 1). W innym miejscu tenże autor pisze, iż w edukacji międzykulturowej różnica kulturowa jest esencjalizowana (Dietz, 2018, s. 11).

Coraz częściej wysuwa się też tezę o niepowodzeniu tej wersji wielokulturowego projektu, której istotą jest współistnienie różnych grup. Uważa się, że w praktyce prowadzi to jedynie do „unikania konfliktów i zachowywania swojej różnicy” (grupowej), co w praktyce doprowadza do „wzajemnej obojętności”, a w najgorszym przypadku do „wzajemnego braku zaufania”. Krytykuje się też kultywowanie tożsamości grupowej, bowiem dzieje się to 
kosztem tożsamości jednostkowej (Roveo, 2019, ss. 62-63). W związku z tym Federico Rovea proponuje, aby skoncentrować uwagę na relacjach między jednostkami, o charakterze stricte interpersonalnym; mają one zastąpić relacje między grupami (Roveo, 2019, s. 63). To z kolei rodzi następne pytanie: czy różnicę kulturową należy postrzegać jako „sprywatyzowaną”, czy jako problem grupowej inkluzji i równości społeczno-ekonomicznej? (Yanasmayan, 2011, s. 25).

Warto przy tym w tym miejscu przywołać jeszcze dwa konteksty omawianych problemów. Oto Elizabeth Anderson twierdzi, że część przedstawicieli współczesnej antropologii, popierając wielokulturowość, akcentuje ideę, iż każda społeczność ma żyć zgodnie ze swoimi normami kulturowymi, wychowywać według nich kolejne pokolenie, ale także posiadać własne „etnocentryczne, auto-segregacyjne impulsy”. Może także bronić się przed „zewnętrznymi wpływami", których źródłem są inne kultury czy globalizacja, bowiem mogą stanowić one „homogenizujące zagrożenie dla kulturowej czystości czy autentyczności" (tak jak jest ona subiektywnie postrzegana przez członków grupy). Twierdzi się też, że trzeba zaakceptować fakt, iż prowadzi to zwykle do powstania dystansu wobec grup, do których się nie należy (Anderson, 2010, s. 77). Trudno jest, na poziomie zdrowego rozsądku, odmówić racji powyższym założeniom, jednakże trzeba być świadomym, że nie sprzyjają one urzeczywistnieniu edukacji międzykulturowej.

Przywołam także rozważania Paula C. Gorskiego, który poddaje krytycznie analizie pojęcie „dialogu międzykulturowego”. Pisze on, iż w pojęcie to wpisane są nieodłącznie „asymetryczne relacje władzy”; odnosi się to na przykład do Czarnych i Białych w Stanach Zjednoczonych czy Południowej Afryce. Istotą dialogu - w założeniu - ma być stworzenie warunków dla rozwoju wzajemnej empatii; tak więc w tym przypadku „oczekuje się od zdominowanych wykazywania empatycznego podejścia wobec osób, które (...) reprezentują ich opresorów" (Gorski, 2008, ss. 520-521). Uważa się przy tym, że to grupy dominujące kontrolują edukację międzykulturową zarówno w szkolnictwie, jak i w mass mediach. W praktyce więc „reifikuje ona hierarchie władzy", zdominowani nie mają w niej znaczącego głosu (Gorski, 2008, s. 521). Można w tym kontekście zadać niezwykle istotne pytanie: czy edukacja międzykulturowa stanowi przede wszystkim projekt tożsamości czy jest także projektem równości społeczno-kulturowej?

I tutaj właśnie pojawia się ważny dylemat współczesnej edukacji międzykulturowej. Oczywiste jest, że w warunkach hybrydyzacji czy rozproszenia tożsamości, a dotyczy to milionów ludzi żyjących w społeczeństwach wielo- 
kulturowych, nie jest uprawomocnione tworzenie „sztucznych” konstruktów grup (czy to rasowych czy etnicznych), między którymi będą odbywać się międzykulturowe interakcje. Taki zabieg byłby rzeczywiście nieuchronnie związany z esencjalizacją tożsamości.

Z drugiej strony jest też dla mnie oczywiste, że niemożliwe jest traktowanie społeczeństwa jako zbioru milionów jednostek, których nie łączą żadne więzi grupowe; postrzeganie ich wyłącznie w kategoriach jednostkowych, hybrydalnych tożsamości. Taka forma edukacji międzykulturowej byłaby nie tylko sprzeczna z jej istotą, tradycją, ale także nierealistyczna. Trudno się zgodzić z tezą, iż istnieją jedynie jednostki, a grupy rasowe czy narodowe przestały istnieć. Rozliczne, istniejące na świecie konflikty narodowościowe, etniczne i rasowe zaprzeczają tezie o prymacie jednostkowej tożsamości nad grupową.

Wydaje się też uzasadnione twierdzenie Martyna Barretta, iż niezależnie od zjawiska hybrydyzacji kultury i tożsamości uczestnicy międzykulturowych interakcji nie postrzegają siebie w „czysto indywidualny” sposób, lecz przede wszystkim - jako członków określonej grupy kulturowej (Barrett, 2013, s. 152), przynajmniej w pierwszej, kluczowej fazie nawiązywania relacji.

Paolo Gomarasca zadaje przy tym bardzo słuszne pytanie: czy rzeczywiście można potwierdzić, że hybrydyzacja - jak się niekiedy twierdzi - zawsze i wszędzie „wzbogaca osoby i kultury”? (Gomarasca, 2013, s. 72). Paolo Gomarasca pisze: „bezkrytyczni zwolennicy hybrydalności mają tendencję do (...) uznawania kulturowego mieszania jako »quasi-magicznego« rozwiązania rozwiązywania problemów w demokratycznym społeczeństwie”. Twierdzi się, że równie dobrze hybrydalność może być redukcjonistyczna wobec tożsamości (Gomarasca, 2013, s. 72).

Nie ulega też dla mnie wątpliwości, że istotą debaty w ramach edukacji międzykulturowej jest nadal konfrontacja uniwersalistycznych aspiracji monokulturowego Zachodu z różnorodnością kulturową (Dietz, 2007, s. 15). Główne cele tej edukacji pozostały bez zmian, chociaż zapewne muszą być umieszczane w nowych realiach, w których występują równolegle zarówno wysiłki asymilacjonistyczne ze strony dominujących, tendencje izolacjonistyczne, jak i multiplikacje tożsamości hybrydalnych.

Wydaje mi się też, że w warunkach Covid-19 przed edukacją międzykulturową stoją zupełnie nowe wyzwania. Związane są one między innymi $\mathrm{z}$ przeniesieniem formalnego kształcenia w sferę wirtualną. W wielu krajach konsekwencją tego jest ograniczenie, sprzyjających rozwijaniu kompetencji międzykulturowych, naturalnych codziennych bezpośrednich relacji między 
przedstawicielami różnych grup narodowych, rasowych i etnicznych. Pokazane jest to znakomicie na przykładzie Meksyku, gdzie w warunkach pandemii nastąpił odwrót od międzykulturowej edukacji (Dietz i Cortés, 2020). Z kolei Marco Catarci wskazuje, iż w niektórych krajach większość dzieci z mniejszości nie ma "technicznego” dostępu do edukacji zdalnej, nie uczestniczy więc w żadnej formie kształcenia (Catarci, 2021), w większości krajów ograniczona też została działalność centrów i ośrodków edukacji międzykulturowej edukacji.

Kolejne wyzwanie dla edukacji międzykulturowej łączy się z faktem, iż Covid-19 spowodował zasadniczy powrót do idei państwa narodowego jako podstawowego aktora życia międzynarodowego oraz decydującego układu odniesienia dla ludzi. Najbardziej spektakularnym przejawem tego zjawiska było zamknięcie granic; posunięcie logiczne w kontekście optymalizacji polityki zdrowotnej, jednocześnie jednak pokazujące, jak krucha jest międzynarodowa wspólnotowość. Ma bez wątpienia rację Josep Maria Antentas, który uważa, że poprzez zamknięcie granic rządy dążą do swoistego „wyizolowania narodu" z globalnego świata, odwołując się do dychotomii „wewnątrz-na zewnątrz”, „oni-my” (Antentas, 2020, s. 433). Podobne podejście prezentuje Elizabeth Cashdan i Matthew Steele, którzy piszą, iż w sytuacji zagrożenia dla grupy następuje wzrost identyfikacji i lojalności wobec grupy (Cashdan, Steele, 2013, s. 59). Oczywiście ma to miejsce zarówno kosztem międzykulturowej empatii, jak i globalnej solidarności (Bieber, 2020, ss. 2, 7-8).

Punktem wyjścia i istotą edukacji międzykulturowej jest przekonanie, iż różnice kulturowe są skonstruowane społecznie. Oczywiście, także i sama edukacja międzykulturowa stanowi społeczną konstrukcję, czego jej przedstawiciele są całkowicie świadomi. Nie ma więc jedynej i ostatecznej wersji edukacji międzykulturowej. Zmienia się ona w odpowiedzi na warunki społeczno-kulturowe świata, w którym istnieje (Nikitorowicz, 2014); są one związane w pewnej przynajmniej mierze ze zjawiskami, które opisałem w moim tekście. Absolutnie nie można postawić tezy, iż edukacja międzykulturowa znajduje się w sytuacji kryzysowej lub że jej możliwości „wyczerpały się". Wręcz przeciwnie, skomplikowana rzeczywistość społeczno-kulturowa, której źródłem są procesy globalizacji, stawia przed nią nowe wyzwania. I to nadaje edukacji międzykulturowej nową - z mojej perspektywy - pełną pozytywnego potencjału dynamikę rozwojową. 


\section{Bibliografia}

Achkasov, V.A. and Rozanova, M.S. 2013. Migrant's Adaptation and Cultural Integration into Urban Multicultural Society: A Case Study in St. Petersburg. OMNES: The Journal of Multicultural Society. 1 (4), pp. 1-31.

Anderson, E. 2010. The Imperative of Integration. Princeton: Princeton University Press.

Antentas, J.M. 2020. Coronavirus: notes on crisis, borders and the future of neoliberalism. Geographica. Helvetica. 75, pp. 431-436.

Barrett, M. 2013. Intercultural competence: a distinctive hallmark of interculturalism? In: Barrett, M. ed. Interculturalism and multiculturalism: similarities and differences. Strasbourg: Council of Europe Publishing, pp. 147-168.

Bieber, F. 2020. Global Nationalism in Times of the COVID-19 Pandemic. Nationalities Papers. Special Issue Article, pp. 1-13. https://www.cambridge.org/core/services/aop-cambridge-core/content/view/3A7F44AFDD6AC117AE05160F95738ED4/S0090599220000355a.pdf/global_nationalism_in_times_of_the_covid_pandemic.pdf. (24.11.2020).

Carey, T.E. 2013. The dimensionality of black nationalism and African-American political participation. Politics, Groups, and Identities. 1 (1), pp. 66-84 .

Cashdan, E. and Steele, M. 2013. Pathogen Prevalence, Group Bias, and Collectivism in the Standard Cross-Cultural Sample. Human Nature. 24, pp. 461-475 .

Catarci, N. 2021. Intercultural Education and Sustainable Development. A Crucial Nexus for Contribution to the 2030 Agenda for Sustainable Development. Social Sciences. 10 (24), pp. 1-18.

Crozier, G. and Davies, J. 2008. 'The trouble is they don't mix': self-segregation or enforced exclusion? Race Ethnicity and Education. 3 (11), pp. 285-301 .

Dennis, F. 1973. The Sociology of Black Separatism, Paper presented at the American Sociological Association annual meeting. New York: American Sociological Association, pp. 1-25. https://files.eric.ed.gov/fulltext/ ED084317.pdf (10.03.2021).

Dietz, G. 2007. Keyword: Cultural Diversity A Guide Through the Debate. Zeitschrift für Erziehungswissenschaft. 10, pp. 7-30.

Dietz, G. 2009. Multiculturalism, Interculturality and Diversity in Education. An Anthropological Approach. Münster: Waxmann Verlag.

Dietz, G. 2018. Interculturality. In: Callan, H. ed. The International Encyc- 
lopedia of Anthropology. John Wiley \& Sons, Ltd. Published, pp. 1-19. https://www.researc hgate.net/publication/327455124_Interculturality (13.03.2021).

Dietz, G. and Cortés, L.S.M. 2020. Mexican intercultural education in times of COVID-19 pandemic. Intercultural Education. 32 (1), pp. 100-107.

D'Souza, D. 1991. Illiberal Education. The Politics of Race and Sex on Campus. New York: Free Press.

Durkee, M.I. and Williams, J.L. 2015. Accusations of Acting White: Links to Black Students' Racial Identity and Mental Health. Journal of Black Psychology. 1 (41), pp. 26-48.

Durkee, M.I., Gazley, E.R., Hope, E.C. and Keels, M. 2019. Cultural Invalidations: Deconstructing the "Acting White" Phenomenon Among Black and Latinx College Students. Cultural Diversity and Ethnic Minority Psychology. Advance online publication, pp. 1-10. https://www.researchgate.net/ publication/332665332_Cultural_Invalidations_Deconstructing_the_Acting_White_Phenomenon_Among_Black_and_Latinx_College_Students. (22.02.2021).

Golec de Zavala, A., Cichocka, A. and Bilewicz, M. 2013. The Paradox of In-Group Love: Differentiating Collective Narcissism Advances Understanding of the Relationship Between In-Group and Out-Group Attitudes. Journal of Personality. 1 (81), pp. 16-28.

Gomarasca, P. 2013. Multiculturalism or Hybridisation? Cultural Mixing and Politics. Diversities. 2 (15), pp. 67-80.

Gorski, P.C. 2008. Good intentions are not enough: a decolonizing intercultural education. Intercultural Education. 6 (19), pp. 515-525.

Green, M.F. 2013, Improving and Assessing Global Learning. Washington: NAFSA.

Iyall Smith, K.E. 2008. Hybrid Identities: Theoretical and Empirical Examinations. In: Iyall Smith, K.E. and Leavy, P. eds. Hybrid Identities: Theoretical and Empirical Examinations. Leiden: Brill, pp. 3-12.

Johnson, L.D. and Pak, Y.D. 2019. Teaching for Diversity: Intercultural and Intergroup Education in the Public Schools, 1920s to 1970s. Review of Research in Education. 1 (43), pp. 1-31.

Jones, R.H. 2013. The paradox of culture in a globalized world. Language and Intercultural Communication. 13 (2), pp. 237-244.

Lafraya, S. 2011. Intercultural learning in non-formal education: theoretical frameworks and starting points. Strasbourg: Council of Europe Publishing. Leach, C.W., Brown, L.M. and Worden, R.E. 2008. Ethnicity and Identity Po- 
litics. In: Kutz, L.R. ed. Encyclopedia of Violence, Peace E Conflict, vol. 1. Oxford: Elsevier, pp. 758-768.

Lehmann, D. and Siebzehner, B. 2008. Self-exclusion as a strategy of inclusion: the case of Shas. Citizenship Studies. 3 (12), pp. 233-247.

Leman, J., Toğuşlu, E. and Sezgin, I.M. 2014. The Manifestation of Identities in a Plural Post-Secular Europe. In: Toğuşlu, E., Leman, J.I. and Sezgin, I.M. eds. New Multicultural Identities in Europe Religion and Ethnicity in Secular Societies. Leuven: Leuven University Press, pp. 9-34.

Lewowicki, T., Ogrodzka-Mazur, E. i Szczurek-Boruta, A. red. 2011. Edukacja międzykulturowa - dokonania, problemy, perspektywy. Cieszyn Warszawa - Toruń: Wydział Etnologii i Nauk o Edukacji Uniwersytetu Śląskiego, Wyższa Szkoła Pedagogiczna ZNP w Warszawie, Wydawnictwo Adam Marszałek.

Marginson, S. and Sawir, E. 2011. Ideas for Intercultural Education. New York: Palgrave Macmillans.

Marotta, V.P. 2008. The hybrid self and the ambivalence of boundaries. Social Identities. 3 (14), pp. 295-312.

Mazzucotelli, F. 2020. Fragments of Lebanon: Sectarianism and the Financial Crisis. IL POLITICO. 1 (LXXXV), pp. 24-42.

Melosik, Z. 2007. Teoria i praktyka edukacji wielokulturowej. Kraków: Oficyna Wydawnicza „Impuls”.

Melosik, Z. 2014. Kultura popularna i tożsamość młodzieży. W niewoli władzy $i$ wolności. Kraków: Oficyna Wydawnicza „Impuls”.

Nayak, A. 2003. Race, Place and Globalization: Youth Cultures in a Changing World. London: Bloomsbury.

Nikitorowicz, J. 2014. Zadania edukacji międzykulturowej w kontekście problemów wielokulturowego świata. Studia Kulturowo-Edukacyjne. 1 (9), ss. 6-25.

Nikitorowicz J. 2017. Tożsamościowe skutki wielokulturowości. Wielość kultur w jednym człowieku czy ekstremizm i separatyzm kulturowy? Lubelski Rocznik Pedagogiczny. 3 (36), ss. 13-24.

Nikitorowicz J. 2019. Hybrydowa tożsamość na kulturowym pograniczu potencjał i problem osobisty i grupowy? Annales Universitatis Mariae Curie-Skłodowska. Paedagogia-Psychologia. 2 (32), ss. 11-22.

O'Halloran, R. et. al. 2017. Contexts, Theoretical Approaches and Best Practices in Intercultural Education in Primary Schools, Ireland, Germany and France. Raport 2017-1-IE01-KA201-025692. http://growfromseeds.eu/ wp-content/uploads/2018/10/Grow-from-seeds-ebook.pdf (10.09.2020). 
Palaiologou, N. 2014. Intercultural Education: Conceptual and Empirical Challenges. London: Routledge.

Portes, A. and Manning, R.D. 2008. The Immigrant Enclave: Theory and Empirical Examples. In: Olzak, S. and Nagel, J. eds. Social Stratification: Class, Race, and Gender in Sociological Perspective. New York: Academic Press, pp. 47-68.

Prun, C.P. 2020. Aspects Regarding Modeling and Simulation of Evolution

Organic Aspects of Human Communities. AUDRI. 2 (13), pp. 30-53.

Rovea, F. 2019. Intercultural education and everyday life: suggestions from Michel de Certeau. Ethics and Education. 1 (15), pp. 62-76.

Rygiel, D. 2018. Neither Eastern nor Western: Cultural Hybrids in Modern British-Asian Fiction. Methis. Studia Humaniora Estonica. 21-22, pp. 50-63.

Stephens, G. 1992. Interracial Dialogue in Rap Music. Call-and-Response in Multicultural Style. New Formations. Spring (18), pp. 62-79.

Street, J. 2010. The Historiography of the Black Panther Party. Journal of American Studies. 2 (44), pp. 351-375.

Swedenborg, T. 1992. Homies in the Hood: Rap's Commodification of Insubordination. New Formations. Winter (18), pp. 53-66.

Taylor, J. 1993. Are You Politically Correct?. In: Beckwith, F.J and Bauman, M.E. eds. Are You Politically Correct?: Debating America's Cultural Standards. Buffalo: Prometheus Books, pp. 15-31.

Wagner, C. 2016. Migration and the Creation of Hybrid Identity: Chances and Challenges. In: Rotaru, I.G., Simion, D.E. and Burcea, V. eds. The Phenomenon of Migration. Harvard Square Symposium, vol. 2. Cambridge: Scientific Press Cambridge, pp. 237-255.

Williams-León, T. 2003. Check all that Apply: Trends and Prospectives Among Asian-descent Multiracials. In: Loretta, I., Winters, L. and DeBose, H.L. eds. New Faces in a Changing America: Multiracial Identity in the 21st Century. Thousand Oaks: Sage Publications, pp. 158-175.

Willis, P. 1981. Learning to Labor: How Working Class Kids Get Working Class Jobs. New York: Columbia University Press.

Wrench, J.S., Michael, W., Corrigan, M.W., McCroskey, J.C. and PunyanuntCarter, N.M. 2006. Religious Fundamentalism and Intercultural Communication: The Relationships Among Ethnocentrism, Intercultural Communication Apprehension, Religious Fundamentalism, Homonegativity, and Tolerance for Religious Disagreements. Journal of Intercultural Communication Research. 1 (35), pp. 23-34. 
Yanasmayan, Z. 2011. Concepts of Multiculturalism and Assimilation. In: Emerson, M. red. Interculturalism. Europe and Its Muslims in Search of Sound Societal Models. Brussells: Center for European Policy Studies, pp. 17-27.

\title{
Isolationism of minorities, hybridization of identity and the dilem- mas of intercultural education
}

\begin{abstract}
The article comprises an analysis of intercultural education dilemmas related to changes of both the global reality and identity. First, the author presents the main ideas of intercultural education and reconstructs the phenomenon of assimilation and isolationism of racial and ethnic minorities in contemporary multicultural societies. He recalls various contexts of enclavization, self-exlclusion, essentialism, also in the schooling system, which lead towards the confirmation of economic and cultural reproduction. The contradiction between minority isolationism and materialization of multicultural education ideas is stressed. Next, the changes of contemporary identity in relation to its hybrydization and inner cultural heterogenity are analysed. Moreover, the author presents trends in criticism of intercultural education, especially towards the idea of dialogue between cultures. He considers various dilemmas which result from the entanglement of intercultural education in the changes of the contemporary multicultural reality. New challenges for intercultural education are considered in the context of Covid-19 pandemic. In conclusion, the author emphasizes his conviction that contemporary intercultural education has a very positive developmental potential in the contemporary world.
\end{abstract}

Keywords: intercultural education, minority isolationism, ethnocentrism, assimilation, hybrid identity

Translated by Zbyszko Melosik 